\title{
Kompetensi Pedagogik Guru dalam Pembelajaran Pendidikan Agama Islam di SMP Negeri 3 Kuripan
}

\author{
Wely Dozan ${ }^{*}$, Roy Bagaskara, ${ }^{2}$ Baiq Sumarni ${ }^{3}$ \\ ${ }^{1}$ Universitas Islam Negeri Sunan Kalijaga Yogyakarta \\ ${ }^{2}$ Universitas Islam Negeri Sunan Kalijaga Yogyakarta \\ ${ }^{3}$ Universitas Islam Negeri Mataram
}

\begin{abstract}
Keywords:
Pedagogical Competence,

Teachers, Islamic Education

Kata Kunci:

Kompetensi Pedagogik, Guru, Pendidikan Agama Islam
\end{abstract}

*Correspondence Address: welydozan77@gmail.com

\begin{abstract}
This research is motivated by education which changes every year and develops along with the times, requiring all parties, especially teachers to improve their competence. Because the teacher is a major component in the education system. Teachers in the teaching and learning process have a very important role in an effort to educate the lives of the people and nation. Therefore, teachers must have competence in teaching which is a skill or skill in managing learning activities. Thus the purpose of this study is to describe the pedagogical competence of teachers in learning Islamic religious education, teacher difficulties in learning and teacher solutions to overcome difficulties in learning Islamic religious education class VII in SMP Negeri 3 Kuripan. The approach used in this research is a qualitative approach, in which data is obtained through interviews, observations, and documentation. The data analysis method is inductive, namely reducing data, presenting data, and drawing conclusions. Based on the results of this study it can be concluded that: 1) Teacher's pedagogical competence in learning Islamic education is good enough which includes: a) The ability to understand students. b) Ability to design learning. $c$ ) The ability to carry out educative and dialogical learning. d) Ability to evaluate. e) The ability to develop students to actualize the various potentials they have. 2) Difficulties in learning which include: a) Different ability of students to absorb. b) Lack of student interest in learning. c) Lack of parents' attention to children's learning. d) Lack of facilities available in schools. 3) Solutions to overcome difficulties in learning are: a) Provide a special and remedial approach for students who are slow to accept material and provide follow-up material for students who are quick to understand. b) Give motivation or encouragement. c) Cooperate with guardian parents. d) Make use of existing media.
\end{abstract}

Abstrak: Penelitian ini dilatarbelakangi oleh pendidikan yang setiap tahunnya berubah dan berkembang seiring dengan perkembangan zaman menuntut semua pihak terutama guru untuk meningkatkan kompetensinya. Karena guru merupakan komponen utama dalam sistem pendidikan Guru dalam proses belajar mengajar memiliki peranan yang sangat penting sebagai upaya untuk mencerdaskan kehidupan masyarakat dan bangsa.oleh karena itu guru harus memiliki kompetensi dalam mengajar yang merupakan kecakapan atau keterampilan dalam mengelola kegiatan pembelajaran. Dengan demikian tujuan penelitian ini adalah untuk mendeskripsikan tentang kompetensi pedagogik guru dalam pembelajaran pendidikan agama Islam, kesulitan guru dalam pembelajaran dan solusi guru untuk mengatasi kesulitan dalam pembelajaran pendidikan agama Islam 


\begin{abstract}
kelas VII di SMP Negeri 3 Kuripan. Pendekatan yang digunakan dalam penelitian ini adalah pendekatan kualitatif, yang mana data diperoleh melalui metode wawancara, observasi, dan dokumentasi. Adapun metode analisis data bersifat induktif yaitu mereduksi data, penyajian data, dan penarikan kesimpulan. Berdasarkan hasil penelitian ini dapat disimpulkan bahwa: 1) Kompetensi pedagogik guru dalam pembelajaran pendidikan agama Islam sudah cukup baik yang meliputi: a) Kemampuan memahami peserta didik. b) Kemampuan merancang pembelajaran. c) Kemampuan melaksanakan pembelajaran yang mendidik dan dialogis. d) Kemampuan melakukan evaluasi. e) Kemampuan mengembangkan peserta didik untuk mengaktualisasikan berbagai potensi yang dimiliki. 2) Kesulitan dalam pembelajaran yang meliputi: a) Kemampuan daya serap peserta didik yang berbeda-beda. b) Kurangnya minat belajar siswa. c) Kurangnya perhatian orang tua terhadap belajar anak. d) Kurangnya fasilitas yang tersedia di sekolah. 3) Solusi untuk mengatasi kesulitan dalam pembelajaran yaitu: a) Memberikan pendekatan khusus dan remedial bagi siswa yang lamban menerima materi dan memberikan materi lanjutan bagi siswa yang cepat paham. b) Memberikan motivasi atau dorongan. c) Bekerja sama dengan orang tua wali. d) Memanfaatkan media yang ada.
\end{abstract}

\section{PENDAHULUAN}

Pendidikan yang setiap tahunnya berubah dan berkembang seiring dengan perkembangan zaman menuntut semua pihak dalam berbagai bidang termasuk guru untuk senantiasa meningkatkan kompetensinya. Guru merupakan komponen paling penting dan menentukan dalam sistem pendidikan secara keseluruhan, yang harus mendapat perhatian sentral, pertama dan utama. ${ }^{1}$ Menurut Nanang Hanafiyah mengatakan bahwa, Guru sebagai pelaku ekonomi kelas memiliki wewenang untuk melakukan reformasi kelas (classroom reform) dalam rangka melakukan perubahan perilaku peserta didik secara berkelanjutan yang sejalan dengan tugas perkembangannya dan tuntutan lingkungan disekitarnya. Guru

1E. Mulyasa, Standar Kompetensi dan Sertifikasi Guru, (Bandung:PT Remaja Rosdakarya, 2011), 5.

2 Cucu Suhana, Konsep Strategi Pembelajaran, (Bandung: PT Refika Aditama, 2014),95-96 sebagai arsitek perubahanperilaku peserta didik dan sekaligus sebagai model panutan para peserta didik dituntut memiliki kompetensi yang paripurna. $^{2}$

Selain itu,guru dalam proses belajar mengajar memiliki peranan yang sangat penting sebagai upaya untuk mencerdaskan kehidupan masyarakat dan bangsa. Karena itu secara teoritis bahwa tinggi rendahnya kualitaspembelajaran sangat ditentukan oleh tinggi rendahnya kompetensi yang dimiliki guru. ${ }^{3}$

Menurut kepmendiknas 045/11/2002 kompetensi adalah "seperangkat tindakan cerdas, penuh tanggung jawab yang di miliki oleh seseorang sebagai syarat untuk dianggap mampu oleh masyarakat

3 Lubna, "Peran Kompetensi Mengajar Guru dalam Memotivasi, Meningkatkan Prestasi Belajar Siawa pada Mata Pelajaran Ekonomi Kelas X SMA Muhammadiyah Mataram Tahun Pelajaran 2008-2009", Jurnal SOCIETY, Nomor 2, Desember 2009, 59. 
dalam melaksanakan tugas-tugas di bidang pekerjaan tertentu". ${ }^{4}$ Sifat inteligen harus di tunjukkan sebagai kemahiran, ketetapan dan keberhasilan bertindak.Sikap tanggung jawab harus ditunjukkan sebagai kebenaran tindakan baik dipandang dari sudut ilmu pengetahuan, teknologi maupun etika.Dalam arti tindakan itu benar ditinjau dari sudut ilmu pengetahuan, efisiensi, efektif dan memiliki daya tarik dilihat dari sudut teknologi, dan baik ditinjau dari sudut etika.Depdiknas merumuskan definisi kompetensi sebagai "pengetahuan, keterampilan dan nilai-nilai dasar yang direfleksikan dalam kebiasaan berfikir dan bertindak.

Dengan demikian, kompetensi yang dimiliki oleh setiap guru akan menunjukkan kualitas guru dalam mengajar. Kompetensi tersebut akan terwujud dalam bentuk penguasaan pengetahuan dan professional dalam menjalankan fungsinya sebagai guru. Artinya guru bukan saja harus pintar tapi juga harus pandai mentransfer ilmunya kepadapeserta didik. ${ }^{5}$ Dalam Standar Nasional Pendidikan Pasal 28 ayat 3 butir a dikemukakan bahwa kompetensi pedagogik adalah "kemampuan mengelola pembelajaran peserta didik, perancangan dan pelaksanaan pembelajaran, evaluasi hasil belajar, dan pengembangan peserta didik untuk mengaktualisasikan berbagai potensi yang dimilikinya". ${ }^{6}$

Salah satu aspek strategis untuk meningkatkan mutu pendidikan pemerintah menetapkan UndangUndang Guru dan Dosen Nomor 14

4Ramayulis, Metodologi Pendidikan Agama

Islam, (Jakarta: Kalam Mulia, 2005), 54.

5Abdul Majid, Perencanaan Pembelajaran

(Mengembangkan Kompetensi Guru), 6.

6E. Mulyasa, Standar Kompetensi dan Sertifikasi Guru, (Bandung: PT Remaja Rosdakarya Offset, 2012),75.
Tahun 2005 menjelaskan bahwa,: Untuk menjamin perluasan dan pemerataan akses, peningkatan mutu dan relevansi, serta tata cara pemerintahan yang baik dan akuntabilitas pendidikan yang mampu menghadapi tantangan sesuai dengan tuntutan perubahan kehidupan lokal, nasional, dan global, perlu dilakukan pemberdayaan dan peningkatan mutu guru dan dosen secara terencana, terarah dan berkesinambungan. ${ }^{7}$

Berdasarkan uraian diatas dapat dipahami bahwa standar kompetensi guru adalah suatu ukuran yang ditetapkan atau yang dipersyaratkan dalam bentuk penguasaan pengetahuan dan berprilaku layaknya seorang guru untuk menduduki jabatan fungsional sesuai bidang tugas, kualifikasi dan jenjang pendidikan.

Standar kompetensi guru bertujuan untuk "memperoleh acuan baku dalam pengukuran kinerja guru untuk mendapatkan jaminan kualitas guru dalam meningkatkan kualitas proses pembelajaran". ${ }^{8} \mathrm{Hal}$ inilah yang menunjukkan bahwa kompetensi pedagogik mempunyai peran penting.Merujuk kepada RPP tentang kompetensi pedagogik guru dalam kemampuan pengelolaan pembelajaran yang meliputi: (a) pemahaman wawasan atau landasan kependidikan; (b) pemahaman terhadap peserta didik; (c) pengembangan kurikulum/ silabus; (d) perancangan pembelajaran; (e) pelaksanaan pembelajaran yang mendidik dan dialogis; (f) evaluasi hasil belajar; (g) pengembangan peserta

7Undang- Undang Nomor 14 Tahun 2005 tentang Guru dan Dosen.

8Abdul Majid, Perencanaan Pembelajaran..., 6. 
didik untuk mengaktualisasikan berbagai kompetensi yang dimilikinya. ${ }^{9}$

Kaitannya dengan kompetensi guru diatas peneliti hanya memfokuskan pada pelaksanaan pembelajaran yang mendidik dan dialogis.Berdasarkan hasil observasi yang peneliti lakukan pada tanggal 6 Maret 2019 di SMP Negeri 3 Kuripan Lombok Barat. Dalam pembelajarannya berlangsung aktif dengan menyuruh para siswa untuk membaca materi secara bergantian,dan hal ini direspon baik oleh para siswa. Pembelajaran yang berlangsung juga tampak kondusif yang ditunjukan dengan masing-masing siswa memperhatikan materi yang disampaikan oleh guru. Guru Pendidikan Agama Islam (PAI) yang ada di SMP Negeri 3 Kuripan tidak hanya menyampaikan materi pembelajaran lewat penjelasan ceramah saja dan menulis di papan tulis, melainkan guru mempraktikkan langsung contoh khutbah jumat. Sehingga dengan contoh ini siswa lebih cepat memahami materi yang diajarkan.

Guru Pendidkan Agama Islam (PAI) tidak hanya menggunakan metode ceramah saja melainkan menggunakan metode tanya jawab dan penugasan. Metode tanya jawab dilakukan dengan cara mempersilahkan siswa untuk bertanya bagian materi yang belum dipahami. Sedangkan di akhir pembelajaran guru memberikan tugas untuk menjawab beberapa pertanyaan yang ada di buku paket.Hal ini dilakukan agar siswa lebih memahami materi yang telah diajarkan.10Namun sebagian kecil hasil belajar peserta didik tergolong masih rendah, terlihat dari

9 Syaiful Sagala, Kemampuan Profesional Guru dan Tenaga Kependidikan, (Bandung: Alfabeta 2009), 32.

100bservasi , Kuripan, 6 Maret 2019

110bservasi, Kuripan, 9 Maret 2019 hasil ulangan harian mereka masih ada siswa yang mendapatkan nilai di bawah standar. ${ }^{11}$

Berdasarkan paparan di atas ,peneliti tertarik untuk melakukan penelitian dengan judul "Kompetensi Pedagogik Guru Dalam Pembelajaran Pendidikan Agama Islam (PAI) Kelas VII Di SMP Negeri 3 Kuripan Tahun Pelajaran 2019/2020" dengan beberapa problematika-problematika yang hendak penulis jawab dalam penelitian ini, Diantaranya: Pertama, Bagaimanakah kompetensi pedagogik guru Pendidikan Agama Islam(PAI) dalam pembelajaran di kelas VII di SMPN 3 kuripan tahun pelajaran 2019/2020. Kedua, Apasajakah kesulitan guru Pendidikan Agama Islam (PAI) dalam pembelajaran di kelas VII di SMPN 3 Kuripan tahun pelajaran 2019/2020. Ketiga, Bagaimanakah solusi guru Pendidikan Agama Islam (PAI) dalam pembelajaran di kelas VII di SPMN 3 Kuripan tahun pelajaran 2019/2020?

\section{KAJIAN TEORI}

Menurut undang-undang Nomor 23 tahun 2005 menjelaskan bahwa kompetensi adalah seperangkat pengetahuan, keterampilan, dan perilaku yang harus dimiliki, dihayati, dan dikuasai oleh guru atau dosen dalam melaksanakan tugas keprofesionalan. ${ }^{12}$ Sedangkan

pengertian dasar dari kompetensi adalah kemampuan atau kecakapan. ${ }^{13}$ Selain itu menurut Huston yang dikutip oleh Samana menjelaskan

12Undang- Undang Nomor 14 Tahu 2005 tentang Guru dan Dosen.

13Maimun, Kiat Sukses Menjadi Guru Halal, (Mataram: (LEPPIM) IAIN Mataram, 2015 ), 25. 
bahwa "kompetensi adalah kemampuan yang ditampilkan oleh guru dalam melaksanakan kewajibannya memberikan pelayanan pendidikan kepada masyarakat."14

\section{Menurut Syaiful Sagala} "kompetensi adalah perpaduan dari penguasaan, pengetahuan, keterampilan, nilai dan sikap yang direfleksikan dalam kebiasaan berpikir melaksanakan tugas/ pekerjaan."15 Sebagaimana perspektif Mc Ahsan dalam E. Mulyasa "kompetensi adalah pengetahuan, keterampilan, dan kemampuan yang dikuasai oleh seseorang yang telah menjadi bagian dari dirinya sehingga ia dapat melakukan perilaku-perilaku kognitif, afektif dan psikomotorik dengan sebaikbaiknya."16

Sedangkan pedagogik merupakan kata yang diserap dari bahasa latin ' pedagogos' yang artinya ilmu mengajar. Kemudian dalam Kamus Besar Bahasa Indonesia (KBBI), kata ini dihadirkan dalam tiga bentuk: (1) Pedagok berarti ahli pedagogi, (2) Pedagogi berarti ilmu pendidikan, ilmu pengajaran, (3) Pedagogis berarti ilmu mendidik. Sedangkan pedagogik menurut istilah berarti sesuatu hal yang berkaitan dengan ilmu mendidik (kegiatan belajar mengajar). ${ }^{17}$

Jadi kompetensi pedagogik adalah "kemampuan guru dalam mengelola pembelajaran peserta didik atau pemahaman guru terhadap peserta didik untuk mengaktualisasikan berbagai kompetensi yang dimiliki."18

14 Hamzah, Profesi Kependidikan, (Gorontalo: Bumi Aksara, 2007),62.

15 Syaiful Sagala, Kemampuan Profesional Guru dan Tenaga Kependidikan....hlm. 29.

16 Maimun, Kiat Sukses Menjadi..., 19.

17 Hamdani, Hubungan Kompetensi Pedagogik dan Motivasi Mengajar dengan Hasil Belajar Siswa Kelas XI pada Mata Pelajaran Fiqih
Berhasil atau tidaknya seorang guru dalam melaksanakan tugasnya sebagai seorang guru tidak sematamata ditentukan oleh ijazah yang dimilikinya, tetapi lebih pada kemampuan aktual yaitu kompetensinya. Oleh sebab itu guru wajib memiliki kualitas akademik, kompetensi, sertifikat pendidikan, sehat jasmani dan rohani, serta memiliki kemampuan untuk mewujudkan tujuan pendidikan. ${ }^{19}$

Agar keberhasilan pendidikan dapat terwujud, diperlukan adanya standar kompetensi. Berdasarkan Peraturan Mentri Pendidikan Nasional Republik Indonesia No 16 tahun 2007 tentang standar kualifikasi akademik dan kompetesi guru pasal 1 menetapkan bahwa "Setiap guru wajib memenuhi standar kualifikasi akademik dan kompetensi guru yang berlaku secara nasional. Standar kualifikasi yang dimaksud ialah diploma empat (DIV) atau (S-1)". ${ }^{20}$

\section{Ciri-ciri kompetensi pedagogik guru}

Menurut Syaiful Sagala kompetensi pedagogik memiliki ciri-ciri sebagai berikut:

a. Memiliki Pemahaman Wawasan atau Landasan Pendidikan

Guru sebagai tenaga pendidik yang sekaligus memiliki peran penting dalam upaya untuk meningkatkan mutu pendidikan di negara ini, terlebih dahulu harus mengetahui dan memahami wawasan dan landasan kependidikan sebagai pengetahuan dasar. Pengetahuan

di MAN 2 Model Medan, Jurnal ANSIRU Nomor 1 Volume 1, Juni 2017, 47-48.

18 Lalu Mukhtar Hully, Profesi Keguruan, (Mataram: Alam Tara Institute, 2012), 24.

19Dani Ronie M, Seni Mengajar dengan Hati, (Palembang: ALTI Publishing House, 2009), 26. 20 Undang-Undang Guru dan Dosen, (Fokusmia: 2011), 136. 
awal tentang wawasan dan landasan kependidikan ini dapat di peroleh ketika guru mengambil pendidikan keguruan di perguruan tinggi. ${ }^{21}$ Agar proses pembelajaran dapat dilaksanakan secara efektif dan efisien, serta mencapai hasil yang diharapkan, diperlukan kegiatan manajemen sistem pembelajaran, sebagai keseluruhan proses untuk melaksanakan pembelajran secara efektif dan efisien. Guru juga merupakan seorang manajer dalam pembelajaran, yang bertanggung jawab terhadap perencanaan, pelaksanaan dan penilaian perubahan atau perbaikan program pembelajaran. ${ }^{22}$

\section{b. Pemahaman Terhadap Peserta Didik} Dijelaskan bahwa pemahaman terhadap peserta didik merupakan salah satu kompetensi pedagogik yang harus dimiliki guru.Setidaknya terdapat empat hal yang harus dipahami guru dari peserta didiknya, yaitu tingkat kecerdasan, kreativitas, cacat fisik dan perkembangan kognitif. ${ }^{23}$

c. Mengembangkan Kurikulum dan Mampu Menyusun Rancangan Pelaksanaan Pembelajaran.

Mampu mengembangkan dan mampu menyusun perencanaan pembelajaran merupakan kegiatan penting dalam pelaksanaan pendidikan di sekolah."Melalui perencanaan pembelajaran yang baik, guru akan lebih mudah dalam melaksanakan pembelajaran dan

21E. Mulyasa, Standar Kompetensi dan Sertifikasi Guru, (Bandung: Remaja Rosdakarya, 2007), 38.

22E. Mulyasa, Standar dan Sertifikasi guru,(Bandung: Remaja Rosdakarya, 2013), 78. siswa akan lebih mudah dalam belajar."24

\section{Pelaksanaan Pembelajaran yang Mendidik dan Dialogis}

Salah satu kompetensi pedagogik yang harus dimiliki oleh seorang guru seperti yang dirumuskan dalam SNP yang berkaitan dengan pelaksanaan pembelajaran.Hal tersebut ditegaskan kembali dalam Rencana Peraturan Pemerintah tentang Guru, bahwa guru harus memiliki kompetensi untuk melaksanakan pembelajaran yang mendidik dan dialogis. Hal ini berarti, bahwa pelaksanaan pembelajaran harus berangkat dari proses dialogis antar sesama subjek pembelajaran, sehingga melahirkan pemikiran kritis dan komunikasi. Tanpa komunikasi tidak akan ada pendidikan sejati.

Pembelajaran yang mendidik dan dialogis merupakan "respon terhadap praktek pendidikan anti realitas, yang menurut Freire (2003) harus diarahkan pada proses hadap masalah". ${ }^{25}$ Dalam pembelajaran, tugas guru yang paling utama adalah mengkondisikan lingkungan agar menunjang terjadinya perubahan perilaku dan pembentukan kompetensi peserta didik. Umumnya pelaksanaan pembelajaran mencakup tiga hal:

1. Pre Tes (tes awal)

Pelaksanaan pembelajaran biasanya dimulai dengan pre tes, untuk menjajagi proses pembelajaran yang akan dilaksanakan. Oleh karena itu, pre tes memegang peranan yang cukup penting dalam proses pembelajaran, yang berfungsi sebagai berikut.

23 Ibid., 79

24Cucu Suhana, Konsep Stretegi Pembelajaran...,hlm. 121. 25Ibid. 
a) Untuk menyiapkan peserta didik dalam proses belajar.

b) Untuk mengetahui tingkat kemajuan peserta didik sehubungan dengan proses pembelajaran yang dilakukan, dengan cara membandingkan hasil pre tes dan post tes.

c) Untuk mengetahui kemampuan awal yang telah dimiliki peserta didik mengenai kompetensi dasar yang akan dijadikan topik dalam proses pembelajaran.

d) Untuk mengetahui dari mana seharusnya proses pembelajaran dimulai, kompetensi dasar mana yang telah dimiliki peserta didik, dan tujuan-tujuan mana yang perlu mendapat penekanan dan perhatian khusus.

2. Proses

Proses dimasudkan sebagai kegiatan inti dari pelaksanaan pembelajaran dan pembentukan kompetensi peserta didik. Proses pembelajaran dan pembentukan kompetensi perlu dilakukan dengan tenang dan menyenangkan, hal tersebut tentu saja menuntut aktivitas dan kreativitas guru dalam menciptakan lingkungan yang kondusif. Proses pembelajaran dan pembentukan kompetensi dikatakan efektif apabila seluruh peserta didik terlibat secara aktif, baik mental, fisik maupun sosial. Untuk itu guru harus menggunakan variasi dalam proses pembelajaran, variasi dalam proses pembelajaran meliputi:

- Variasi dalam penggunaan metode

- Variasi dalam menggunakan media dan sumber belajar

- Variasi dalam memberikan contoh dan ilustrasi.26

\section{Post Tes}

Pada umumnya pelaksanaan pembelajaran diakhiri dengan post tes. Seperti halnya pre tes, post tes memiliki banyak kegunaan, terutama dalam melihat keberhasilan pembelajaran. Fungsi post tes antara lain sebagai berikut:

a. Untuk mengetahui tingkat penguasaan peserta didik terhadap kompetensi yang telah di tentukan, baik secara individu maupun kelompok. Hal ini dapat di ketahui dengan membandingkan hasil pre tes dan post tes.

b. Untuk mengetahui kompetensi dasar dan tujuan-tujuan yang dapat dikuasai oleh peserta didik, serta kompetensi dasar dan tujuan-tujuan yang belum dikuasainya. Sehubungan dengan kompetensi dasar dan tujuan yang belum dikuasai ini, apabila sebagian besar belum menguasainya maka perlu dilakukan pembelajaran kembali (remedial teaching).

c. Untuk mengetahui peserta didik yang perlu mengikuti kegiatan remedial, dan perlu mengikuti kegiatan pengayaan, serta untuk mengetahui tingkat kesulitan belajar.

d. Sebagai bahan acuan untuk melakukan perbaikan terhadap proses pembelajaran dan pembentukan kompetensi peserta didik yang telah dilaksanakan, baik terhadap perencanaan, pelaksanaan maupun evaluasi. ${ }^{27}$

Berdasarkan paparan di atas dapat disimpulkan bahwa seorang guru harus mampu melaksanakan pembelajaran yang mendidik dan dialogis, dimana 
dalam pelaksanaannya guru harus mampu menggunakan metode yang bervariasi, memilih media yang baik, sumber belajar, danguru harus mampu menciptakan lingkungan belajar yang kondusif agar menunjang terjadinya perubahan perilaku pada peserta didik.

\section{METODE}

Metode penelitian pada dasarnya merupakan cara ilmiah untuk mendapatkan data dengan tujuan dan kegunaan tertentu. Cara ilmiah berarti kegiatan penelitian itu di dasarkan pada ciri-ciri keilmuan yaitu rasional (masuk akal), empiris (dapat diamati oleh indra), dan sistematis (menggunakan langkah-langkah tertentu yang bersifat logis). Penelitian merupakan suatu kegiatan (ilmiah) yang di tempuh melalui serangkaian proses yang panjang. ${ }^{28}$ Adapun pendekatan yang dipakai dalam penelitian ini adalah penelitian kualitatif, yakni "penelitian yang bertujuan untuk memahami setiap fenomena yang dialami oleh subjek penelitian, baik tentang perilaku, tindakan, persepsi dan motivasi. Dengan cara deskripsi berupa kata-kata dan bahasa pada suatu konteks khusus dan memanfaatkan berbagai metode yang alamiah". ${ }^{29}$

Sedangkan Margono mendefinisikan bahwa.Penelitian kualitatif adalah teradisi terhadap manusia dalam kawasannya sendiri dan berhubungan dengan orang-orang tersebut dalam bahasanya dan dalam peristiwanya.Lebih jauh lagi, Margono menjelaskan bahwa "penelitian kualitatif memerlukan ketajaman analisis, objektifitas, dan sistematika

28 Burhan Bungin, Metode Penelitian Kualitatif, (Jakarta: Raja Grafindo Persada, 2011), 75. sehingga diperoleh ketepatan dalam interpretasi, sebab hakikat dari suatu fenomena atau gejala bagi penganut penelitian kualitatif adalah "totalitas atau gestalt.Pertimbangan peneliti dalam penggunaan dan penafsirsn makna yang terkandung dalam fenomena temuan sangat diperlukan". 30

\section{Pertimbangan dilakukan}

dengan cara menetapkan kategori yang lain, dan menentukan kriteria yang akan digunakan dalam penelitian kualitatif lebih bersifat deskriptif analiatik yang berarti interpretasi terhadap isi yang dibuat dan disusun secara sistematik atau menyeluruh dan sistematis Berdasarkan pendekatan yang di atas, peneliti tidak hanya mengumpulkan dan menyusun data, tetapi juga menganalisis, menginterpretasikan dalam waktu yang bersamaan. Peneliti ingin mengetahui hal-hal yang terkait dengan kompetensi pedagogik guru dalam pembelajaran Pendidikan Agama Islam (PAI) kelas VII di SMP Negeri 3 Kuripan tahun pelajaran 2019/2020, kemudian kesulitan guru dalam pelaksanaan kompetensi pedagogik dan solusi guru dalam mengatasi kesulitan tersebut.

\section{HASIL DAN PEMBAHASAN \\ Kompetensi Pedagogik Guru dalam Pembelajaran Pendidikan Agama Islam Kelas VII di SMPN 3 Kuripan Tahun Pelajaran 2018/2019}

Pada bagian ini, uraian selanjutnya peneliti ingin menyajikan hasil penelitian berupa data yang diangkat dari hasil observasi dan wawancara yang peneliti lakukan dengan kepala sekolah, guru pendidikan

29Lexy J. Moleong, Metode Penelitian Kualitatif (Edisi Revisi), (Bandung: PT Remaja Rosdakarya, 2011), 6.

30 Margono, Metodologi Penelitian Pendidikan, (Jakarta: Renika, 2004), 36. 
agama Islam dan siswa/siswi kelas VII di SMPN 3 Kuripan, kecamatan Kuripan, Lombok Barat, tentang kompetensi pedagogik guru dalam pembelajaran pendidikan agama Islam.

Pendidikan merupakan suatu proses komunikasi antara pendidik dengan peserta didik dalam pembelajaran yang disampaikan berupa isi/ajaran yang secara seimbang agar tujuan pendidikan dapat tercapai sesuai dengan yang diharapkan. Untuk mencapai tujuan tersebut, maka memerlukan komponen yang mendukung proses pendidikan yang berlangsung salah satunya adalah guru, dimana guru harus menyadari bahwa ia adalah komponen utama dalam pendidikan. Untuk itulah guru dituntut untuk memiliki kompetensi.Kompetensi pedagogik guru dalam pembelajaran Pendidikan Agama Islam meliputi:

1. Kemampuan dalam memahami peserta didik

Peserta didik memiliki karakteristik yang berbeda-beda antara satu dengan yang lainnya, baik dari segi minat, bakat, motifasi, daya serap dalam mengikuti pelajaran, tingkat perkembangan dan tingkat kecerdasan.Hal ini merupakan faktor yang ikut dalam mempengaruhi prestasi belajar anak.

Berdasarkan hasil observasi yang peneliti lakukan kepada guru pendidikan agama Islam, ibu Baiq Fatwini, S.Ag bahwa dalam prosesbelajar mengajar beliau tidak membeda-bedakan antara peserta didik yang memiliki kemampuan diatas rata-rata dengan peserta didik yang memiliki kemampuan rendah, justru yang beliau lakukan adalah mengelompokkan antara peserta didik yang memiliki kemampuan lebih dengan yang kurang, sehingga mereka bisa saling melengkapi satu sama lain. Namun bila ada peserta didik yang belum memahami atau mengerti beliau menjelaskan kembali sampai peserta didik tersebut benar-benar paham apa yang diajarkan. Beliau juga memastikan bahwa semua peserta didiknya mendapatkan kesempatan yang sama untuk berpartisifasi aktif dalam pembelajaran. ${ }^{31}$

Hal ini dikuatkan oleh hasil wawancara peneliti dengan siswa kelas VII Lalu Rian Saputra, yang mengatakan bahwa:

"saya selaku peserta didik sering mengalami kesulitan dalam belajar, khususnya pelajaran pendidikan agama Islam, ibu Baiq Fatwini sering mengunjungi saya dan menjelaskan kembali materi yang tidak saya mengerti. Selain itu beliau juga memberikan saya tugas tambahan agar saya bisa belajar kembali dirumah."32

Selanjutnya hasil wawancara yang dilakukan oleh peneliti kepada siswi kelas VII Yuliatun Hasanah, yang mengatakan bahwa:

"Hasil belajar saya pada mata pelajaran pendidikan agama Islam cukup bagus dikarenakan ibu Baiq Fatwini selalu mengajar dan mendidik saya dengan baik, beliau juga disiplin dan sabar. Di samping itu juga beliau tidak pernah membedakan murid yang pintar ataupun yang bodoh,

32 Wawancara, Lalu Rian Saputra, Siswa Kelas VII, Kuripan, 24 Mei 2019 
beliau selalu bersikap adil kepada murid-muridnya."33

Hal ini juga senada dengan hasil wawancara peneliti dengan wakil kepala sekolah bapak Abdul Waris, S.Pd.I yang mengatakan bahwa:

Dalam memahami peserta didiknya ibu Baiq Fatwini memberikan kesempatan belajar yang sama kepada peserta didik, tidak membeda-bedakan mereka. Beliau juga memberikan bimbingan khusus bagi peserta didik yang memiliki kemampuan rendah, ibu Baiq Fatwini juga merupakan guru yang memiliki kedisiplinan yang tinggi, terlihat ketika beliau selalu datang tepat waktu. ${ }^{34}$

Berdasarkan paparan diatas, seorang guru dituntut untuk mampu memahami peserta didiknya dengan baik demi kelancaran proses belajar mengajar, agar apa yang telah direncanakan bisa berjalan dengan baik, sehingga bisa mencapai tujuan yang telah ditentukan.

2. Kemampuan dalam membuat rancangan pembelajaran (RPP).

Guru harus mampu menetapkan berbagai pendekatan, strategi, metode dan teknik pembelajaran yang mendidik secara kreatif sesuai dengan standar kompetensi guru. Guru hendaknya menyesuaikan metode pembelajaran yang digunakan sesuai dengan karakteristik peserta didik

. Dengan kata lain seorang guru harus mampu membuat rancangan pembelajaran dengan baik sesuai

33Wawancara, Yuliatun Hasanah, Siswi kelas VII, Kuripan, 24 Mei 2019

34 Wawancara, Abdul Waris, Wakil Kepala Sekolah, Kuripan, 25 Mei 2019 dengan komponen-komponen yang terdapat dalam RPP.

Berdasarkan hasil pengamatan peneliti terhadap RPP yang dibuat oleh ibu Baiq Fatwini, S.Agbahwa RPP yang beliau buat cukup baik, karena di dalam RPP tersebut semua komponen-komponen yang harus ada dalam RPP sudah di cantumkan yang meliputi: Identitas sekolah, identitas mata pelajaran, kelas/semester, materi pokok, alokasi waktu, tujuan pembelajaran, kompetensi inti dan indicator pencapaian kompetensi, materi pembelajaran, metode, pende pendekatan , media, sumber belajar, langkah-langkah pembelajaran dan penilaian hasil pembelajaran. ${ }^{35}$

Berdasarkan paparan diatas dapat dipahami bahwa seorang guru harus mampu menyusun rencana pelaksanaan pembelajaran dengan sebaik mungkin, karena hal itulah yang dijadikan sebagai acuan dalam melaksanakan proses belajar mengajar.

3. Kemampuan melaksanakan pembelajaran yang mendidik dan dialogis

Kemampuan meyelenggarakan pembelajaran yang mendidik yaitu guru mampu menyusun dan melaksanakan rancangan pembelajaran yang mendidik secara lengkap, pembelajaran yang sesuai dengan kebutuhan peserta didik, menggunakan berbagai macam metode, dan memilih media yang baik. Ada beberapa hal yang dapat dilakukan yakni:

35 Dokumentasi , (RPP) Guru PAI Kelas VII , Kuripan, 23 Mei 2019 
a. Membuka pelajaran

Menyampaikan tujuan pembelajaran yang akan dicapai, memotivasi siswa dan mengaitkan materi yang akan dipelajari dengan materi sebelumnya atau keadaan yang sedang terjadi pada saat itu.

Berdasarkan hasil observasi yang peneliti lakukan kepada guru pendidikan agama Islam yaitu ibu Baiq Fatwini, S.Ag bahwa dalam membuka pelajaran beliau memulai dengan berdoa,menyampaikan tujuan pembelajaran yang akan dicapai, memotivasi siswa dan mengaitkan materi yang dipelajari dengan materi sebelumnya. ${ }^{36}$

Hal ini senada dengan hasil wawancara peneliti dengan siswi kelas VII Diana Ayu, yang mengatakan bahwa:

"Dalam proses belajar
mengajar ibu Fatwini
memulai pelajaran dengan
menyuruh kami untuk
berdoa setelah itu beliau
menyampaikan tujuan dari
pembelajaran yang akan
dicapai, memberikan
motivasi dan mengaitkan
materi yang lalu dengan
materi yang akan di
pelajari."37

b. Mengelola kegiatan belajar mengajar

Menjelaskan materi, menggunakan metode, memberi contoh sesuai dengan materi yang diajarkan, menggunakan media pembelajaran, memberi pertanyaan dan menekankan hal-hal yang menumbuhkan kebiasaan positif pada tingkah laku siswa.

Berdasarkan hasil observasi yang peneliti lakukan kepada guru pendidikan agama Islam, Baiq Fatwini, S.Ag bahwa dalam mengelola kegiatan belajar mengajar beliau terlebih dahulu membagi peserta didiknya menjadi 5 kelompok, kemudian peserta didik diminta untuk membuka buku paket yang telah disediakan, setelah itu beliau menjelaskan materi secara rinci, mulai dari materi yang mudah sampai dengan materi yang sulit, beliau juga menyampaikan materinya dengan jelas, menggunakan bahasa yang baik, sehingga peserta didik paham terhadap apa yang disampaikan oleh beliau. Dalam kegiatan belajar mengajar beliau menggunakan metode yang bervariasi seperti ceramah, diskusi, tanya jawab, demonstrasi dan penugasan, sehingga dengan metode yang bervariasi ini peserta didik tidak merasa bosan ataupun jenuh dalam menerima pelajaran .Namun dalammenggunakan media beliau masih menggunakan media yang sederhana seperti papan tulis, kertas dan media orang. Dikarenakan fasilitas yang disediakan oleh sekolah belum memadai ${ }^{38}$.

Hal ini diperkuat oleh hasil wawancara peneliti dengan siswi 
kelas VII Nurul Wahida yang menyatakan bahwa:

Ketika proses belajar mengajar berlangsung ibu Baiq Fatwini, S.Ag menjelaskan materi secara jelas, menggunakan bahasa yang mudah kami pahami, beliau juga menggunakan metode yang bervariasi, selain itu beliau juga memberikan contoh secara langsung agar kami bisa langsung paham, sehingga saya dapat mempraktikan langsung contoh yang diberikan dalam kehidupan sehari-hari. ${ }^{39}$

Berdasarkan pemaparan siswa lain yang diwawancara peneliti juga mengutarakan hal yang sama terkait pembelajaran mata pelajaran Pendidikan Agama Islam di sekolah mereka. Hal ini menunjukkan hasil yang baik bagi pemahaman kompetensi pedagogik guru di SMPN 3 Kuripan.

\section{Analisis Kompetensi Pedagogik Guru dalam Pembelajaran Pendidikan Agama Islam (PAI) Kelas VII di SMP Negeri 3 Kuripan Tahun Pelajaran 2018/2019}

Berdasarkan paparan data-data penelitian mengenai kompetensi pedagogik guru dalam pembelajaran Pendidikan Agama Islam (PAI) kelas VII di SMP Negeri 3 Kuripan tahun pelajaran 2018/2019 bahwa, kompetensi pedagogik

Kompetensi pedagogik adalah kemampuan guru dalam mengelola pembelajaran peserta didik. Kompetensi pedagogik meliputi:

39Wawancara, Nurul Wahida, Siswi Kelas VII, Kuripan, 24 Mei 2019
1. Pemahaman terhadap peserta didik

Pemahaman terhadap peserta didik merupakan salah satu kompetensi pedagogik yang harus dimiliki oleh seorang guru. Guru dalam memahami peserta didiknya harus memperhatikan perkembangan kognitif, bekal ajar awal, dan perkembangan kepribadian ${ }^{40}$

$$
\text { Pemahaman }
$$

guru

terhadap peserta didik dilakukan oleh guru pendidikan agama Islam dengan melihat kemampuan mereka masingmasing, sehingga tidak membeda-bedakan mereka dalam memberikan fasilitas belajar. Selain itu guru pendidikan agama Islam memberikan bimbingan khusus bagi peserta didik yang memiliki kemampuan di bawah rata-rata.

2. Merancang pelaksanaan pembelajaran (RPP)

Rencana Pelaksanaan Pembelajaran (RPP) adalah rencana yang menggambarkan prosedur dan pengorganisasian pembelajaran untuk mencapai satu kompetensi dasar yang ditetapkan dalam standar isi dan telah dijabarkan dalam silabus. Berdasarkan Standar Proses No.65 Thn 2013, maka komponen RPP terdiri atas: Identitas sekolah, identitas mata pelajaran, kelas/semester, materi pokok,alokasi waktu, tujuan pembelajaran, kompetensi dasar dan indicator pencapaian kompetensi, materi pembelajaran, metode, media, 
sumber belajar, langkah-langkah pembelajaran dan penilaian hasil pembelajaran. ${ }^{41}$

Rencana pelaksanaan pembelajaran yang dibuat oleh guru pendidikan agama Islam sudah cukup baik, dalam membuat sebuah RPP beliau mengacu pada komponenkomponen yang terdapat dalam RPP.

3. Melaksanakan pembelajaran yang mendidik dan dialogis Pelaksanaan pembelajaran yang mendidik dan dialogis merupakan respon terhadap praktek pendidikan anti realitas, yang menurut Freire (2003) harus diarahkan pada proses hadap masalah. Pembelajaran harus berangkat dari proses dialog antara pendidik dengan peserta didik sehingga melahirkan pemikiran dan komunikasi. Karena pembelajaran pada hakikatnya adalah proses interaksi antara peserta didik dengan lingkungan, sehingga terjadi perubahan perilaku kearah yang lebih baik. Proses dalam pembelajaran meliputi tes awal, proses atau kegiatan inti, dan tes akhir. ${ }^{42}$

Dalam melaksanakan pembelajaran yang mendidik dan dialogis guru pendidikan agama Islam melaksanakan dengan beberapa langkah yakni membuka pelajaran sebagai langkah tes awal yang di dalamnya terdapat kegiatan seperti apersepsi, motivasi dan menyampaikan tujuan dari pembelajaran. Proses atau kegiatan inti yang dilaksanakan

41 Ramayulis, Metodologi Pendidikan Agama Islam, (Jakarta: Kalam Mulia, 2005), 169-170. meliputi pertama mengelola kegiatan belajar mengajar yang di dalamnya terdapat kegiatan menjelaskan materi secara rinci, menggunakan metode yang bervariasi, menggunakan media, memberi, pertanyaan, dan memberikan contoh secara langsung materi yang dipelajari. Kedua berkomunikasi dengan peserta didik yang di dalamnya terdapat kegiatan memberi kesempatan untuk bertanya pada peserta didik bagian materi yang belum dipahami, dengan menggunakan bahasa yang baik dan jelas sehingga peserta didik paham terhadap apa yang disampaikan. Ketiga menggunakan waktu dengan baik sesuai dengan RPP yang telah dibuat agar pembelajaran di kelas dapat berlangsung dengan baik dan tepat waktu.Keempatmenguasai kelas dengan cara menciptakan lingkungan belajar yang kondusif. Kelimamelakukan penilaian selama proses belajar mengajar berlangsung yakni dengan cara memberikan pertanyaan, dan memberikan soal untuk dikerjakan diakhir pembelajaran. Menutup pelajaran sebagai post tes yang di dalamnya terdapat kegiatan menyimpulkan, melakukan refleksi atau membuat rangkuman dengan melibatkan peserta didik dan memberikan tugas.

\section{Mengevaluasi hasil belajar}

42 E. Mulyasa, Standar Kompetensi dan Sertifikasi Guru, (Bandung: PT Remaja Rosdakarya Offset), 103-105. 
Evaluasi merupakan hal yang sangat penting yang harus dilakukan oleh seorang guru.Dengan adanya evaluasi guru bisa mengetahui sejauh mana pemahaman peserta didik terhadap materi yang telah diajarkan.Dan sebagai acuan untuk melaksanakan pembelajaran selanjutnya. Evaluasi dapat dilakukan dengan dua cara yaitu evaluasi proses dan evaluasi hasil. Evaluasi proses dilakukan pada saat proses belaja mengajar berlangsung dan evaluasi hasil dilakukan pada akhir pembelajaran dengan cara penilaian kelas yang meliputi ulangan harian, ulangan umum dan ujian akhir. 43

Evaluasi yang dilakukan oleh guru pendidikan agama Islam dengan cara memberikan pertanyaan pada saat proses belajar mengajar, memberikan tugas, dan ulangan harian.

5. Pengembangan pesertadidik untuk mengaktualisasikan berbagai potensi yang dimilikinya.

Guru dalam melakukan pengembangan peserta didik untuk mengaktualisasikan berbagai potensi yang dimilikinya dapat dilakukan dengan berbagai cara, antaralain melalui kegiatan ekstra kurikuler, pengayaan dan remedial. 44

\section{Guru pendidikan}

agama Islam yang ada di SMP Negeri 3 Kuripan melakukan pengembangan peserta untuk mengaktualisasikan berbagai potensi yang dimilinya dengan cara mengarahkan mereka pada hal-hal yang bersifat fositif yang mengarah pada bidang keagamaan yakni dengan membiasakan peserta didiknya untuk membaca Al- Quran setiap pagi sebelum mereka masuk kelas, selain itu guru pendidikan agama Islam memberikan remedial kepada peserta didik yang memilki kemampuan dibawah rata-rata.

Berdasarkan data yang didapat oleh peneliti terkait dengan kompetensi pedagogik guru dalam pembelajaran PAI di kelas VIIdi SMP Negeri 3 Kuripan bahwa guru memilki kompetensi pedagogik tersebutdan telah menerapkan dalam pembelajaran, meskipun belum sempurna karena adanya hambatan-hambatan seperti kurangnya fasilitas yang tersedia di sekolah.

\section{KESIMPULAN}

Berdasarkan hasil penelitian dan pembahasan dalam skripsi ini, maka peneliti dapat menarik kesimpulan sKompetensi pedagogik guru dalam pembelajaran pendidikan agama Islam cukup baik, yang meliputi: a) Kemampuan dalam memahami peserta didik, b) Kemampuan merancang pembelajaran, c) Kemampuan melaksanakan pembelajaran yang mendidik dandialogis, d) Kemampuan dalam melakukan evaluasi hasil belajar, dan d) Kemampuan guru dalam mengembangkan peserta didik untuk mengaktualisasikan berbagai potensi yang dimilikinya. 


\section{REFERENSI}

Abdul Majid, Perencanaan

Pembelajaran (Mengembangkan

Kompetensi Guru.

Burhan Bungin, Metode Penelitian Kualitatif, Jakarta: Raja Grafindo Persada, 2011.

Cucu Suhana, Konsep Strategi Pembelajaran, Bandung: PT Refika Aditama, 2014.

Dani Ronie M, Seni Mengajar dengan Hati, Palembang: ALTI Publishing House, 2009.

Dani Ronie M, Seni Mengajar dengan Hati, Palembang: ALTI Publishing House, 2009.

Dokumentasi , (RPP) Guru PAI Kelas VII , Kuripan, 23 Mei 2019

E. Mulyasa, Standar Kompetensi dan Sertifikasi Guru, Bandung:PT Remaja Rosdakarya, 2011.

Hamdani, Hubungan Kompetensi Pedagogik dan Motivasi Mengajar dengan Hasil Belajar Siswa Kelas XI pada Mata Pelajaran Fiqih di MAN 2 Model Medan, Jurnal ANSIRU Nomor 1 Volume 1, Juni 2017.

Hamdani, Hubungan Kompetensi Pedagogik dan Motivasi Mengajar dengan Hasil Belajar Siswa Kelas XI pada Mata Pelajaran Fiqih di MAN 2 Model Medan, Jurnal ANSIRU Nomor 1 Volume 1, Juni 2017.

Hamzah, Profesi Kependidikan, Gorontalo: Bumi Aksara, 2007.

Lalu Mukhtar Hully, Profesi Keguruan, Mataram: Alam Tara Institute, 2012.

Lalu Mukhtar Hully, Profesi Keguruan, Mataram: Alam Tara Institute, 2012.
Lexy J. Moleong, Metode Penelitian Kualitatif (Edisi Revisi), Bandung: PT Remaja Rosdakarya, 2011.

Lubna, "Peran Kompetensi Mengajar Guru dalam Memotivasi, Meningkatkan Prestasi Belajar Siawa pada Mata Pelajaran Ekonomi Kelas X SMA Muhammadiyah Mataram Tahun Pelajaran 2008-2009", Jurnal SOCIETY, Nomor 2, Desember 2009.

Maimun, Kiat Sukses Menjadi Guru Halal, Mataram: (LEPPIM) IAIN Mataram, 2015.

Margono, Metodologi Penelitian Pendidikan, Jakarta: Renika, 2004.

Observasi , Kuripan, 6 Maret 2019

Observasi ,Kuripan, 25 Mei 2019

Observasi, Kuripan, 23 Mei 2019

Observasi, Kuripan, 23 Mei2019

Observasi, Kuripan, 9 Maret 2019

Ramayulis, Metodologi Pendidikan Agama Islam, Jakarta: Kalam Mulia, 2005.

Ramayulis, Metodologi Pendidikan Agama Islam, Jakarta: Kalam Mulia, 2005

Syaiful Sagala, Kemampuan Profesional Guru dan Tenaga Kependidikan, Bandung: Alfabeta 2009.

Undang- Undang Nomor 14 Tahun 2005 tentang Guru dan Dosen

Undang-Undang Guru dan Dosen, Fokusmia: 2011.

Wawancara, Abdul Waris, Wakil Kepala Sekolah, Kuripan, 25 Mei 2019

Wawancara, Diana Ayu Siswi Kelas VII, Kuripan, 20 Desember 2019

Wawancara, Lalu Rian Saputra, Siswa Kelas VII, Kuripan, 24 Mei 2019 


\section{Wawancara, Nurul Wahida, Siswi Kelas}

VII, Kuripan, 24 Mei 2019

Wawancara, Yuliatun Hasanah, Siswi

kelas VII, Kuripan, 24 Mei 2019 